\title{
Notes on Casuarinaceae III: The new genus Ceuthostoma
}

\author{
L.A.S. Johnson
}

\begin{abstract}
Johnson, L.A.S. (Royal Botanic Gardens, Sydney, Australia 2000) 1988. Notes on Casuarinaceae III: The new genus Ceuthostoma. Telopea 3(2): 133-137. Ceuthostoma L. Johnson, gen. nov., and its two species, C. palawanense L. Johnson and C. terminale L. Johnson, are described. A synoptic key to the four genera of the family is given.
\end{abstract}

Four genera can be recognised in the family Casuarinaceae: Casuarina, Gymnostoma (Johnson 1980), Allocasuarina (Johnson 1982) and Ceuthostoma, a small genus in the Malesian region. Preparation of a treatment of the family for 'Flora Malesiana' makes it desirable to describe this fourth genus and its two species now. Postulated phylogenetic relationships in the family will be discussed in a separate, more extensive paper.

The four genera of Casuarinaceae can be distinguished as in the following synoptic key:

1 Furrows of branchlets shallow and open, exposing the stomates; teeth 4 per whorl; infructescences on long or short branchlets that are similar to vegetative branchlets, and with a broad bract beneath each pair of bracteoles; samaras grey to pale brown; seed short-lived. $x=8$. NE. Qld, Malesia to New Caledonia and Fiji ................................. Gymnostoma L. Johnson

$1^{*}$ Furrows of branchlets deep and narrow, the stomates not visible; infructescences with more or less thin and inconspicuous bracts ......................... 2

2 Infructescences on long branchlets that are similar to vegetative branchlets, with relatively very long bracteoles protruding antrorsely; teeth 4 ; samaras pale brown; seed probably short-lived. Chromosome number unknown. Palawan and Borneo to New Guinea

Ceuthostoma L. Johnson

$2^{*}$ Infructescences on short modified woody branchlets ('peduncles'), with very short to long bracteoles protruding at c. 90 degrees to the vertical axis of the infructescence

3 Samaras grey or yellow-brown, dull; bracteoles of infructescences thin and without any dorsal protuberances; teeth 5 to many; seed short-lived. $x=9$. SE. Asia to Pacific Islands, mainland Australia Casuarina L.

$3^{*}$ Samaras red-brown to black, shining; bracteoles of infructescences thick and convex, mostly with an angular, divided or spiny dorsal protuberance; teeth 4 to many; seed long-lived. $x=10,11,12,13,14$. Australia

Allocasuarina L. Johnson

Ceuthostoma L. Johnson, gen. nov.

Arbores verisimiliter dioicae. Ramuli persistentes novelli eis deciduis similes; ramuli omnes quadricostati, sulcis intercostalibus profundis fere clausis, seriebus stomatum abditis. Folia 4 in verticillo unoquoque. Inflorescentiae masculae adhuc 
ignotae; spiculae foemineae in ramulis elongatis vel mediocribus sed aspectu eis vegetativis similibus dispositae. Infructescentiae plerumque inter ramulos assimilantes dispositae; bracteae distaliter aliquantum expansae facie abaxiali infra apicem contractum acutumque verticali manifestaque, altiore quam latiore vel dimensionibus subaequalibus; bracteolae valde protrudentes textura non valde lignosa, in dorso convexae sed nec fissae nec protuberatione instructae. Chromosomata adhuc ignota.

Species TypicA: C. terminale L. Johnson.

Trees, apparently dioecious. New persistent branchlets similar to deciduous branchlets; all branchlets longitudinally 4-ribbed, the furrows between the phyllichnia deep and almost closed, hiding the rows of stomates. Leaves 4 per whorl. Male inflorescences not known. Female inflorescences on at least moderately long branchlets that are similar to the vegetative branchlets. Infructescences ('cones') usually found amongst the assimilatory branchlets; cone body longer than broad or subequal in dimensions; cone bracts somewhat expanded distally, having an obvious vertical abaxial face below the contracted acute apex; bracteoles strongly protruding antrorsely relative to the vertical axis of the body, not strongly woody in texture, convex dorsally and the dorsal eccentric rib obvious, but without protuberances and not striate; samara pale brown, dullish.

Two species in Malesia, from Palawan and Borneo to New Guinea.

The name is derived from Greek keuthos = 'hidden' and stoma = 'mouth', referring to the concealed position of the stomates in the branchlet furrows, in contrast to Gymnostoma. The gender is neuter. In English usage, the stress is on the second syllable, as it is in 'Gymnostoma'.

Ceuthostoma resembles Gymnostoma in general aspect and in its constantly 4-merous whorls of reduced leaves. It differs from that genus in that the stomatal depressions between the phyllichnia* are deep and virtually closed by appression of their rims, as in Casuarina and Allocasuarina. The infructescences are very small and delicate, with less broadened and less woody bract-faces than in Gymnostoma. The infructescence is also distinctive in consisting of only a few $(1-2(-3))$ fertile whorls and in having the relatively long bracteoles protruding antrorsely to the vertical axis of the cone body, not at 90 degrees as in Gymnostoma. Unfortunately, no staminate material has yet been collected, and the chromosome number is not yet known. The stomate-bearing furrows formed by the edges of the phyllichnia may be synapomorphous with the similiar condition in Casuarina and Allocasuarina; on the other hand the fruiting bracteole shape may be a synapomorphy with Gymnostoma. The muchbroadened fruiting bracts of Gymnostoma are probably an apomorphy for that genus.

I had previously included these two species, both hitherto undescribed, in Gymnostoma, and specimens in a number of herbaria bearing my determinations under that generic name will need to be removed to Ceuthostoma.

\footnotetext{
*The term phyllichnium (pl. phyllichnia) was introduced by Loew (1865) and is useful to refer to a characteristic feature of Casuarinaceae. It refers to the ridges on the articles of the 'branchlet', which contain a foliar vascular strand for their full length and may be regarded as elongated and modified leaf-base regions, though more traditionally described as 'leaves concrescent with the axis'.
} 
1 Branchlet articles 4-7 $\mathrm{mm}$ long, 0.7-0.9 $\mathrm{mm}$ diameter; phyllichnia with a rounded ridge; teeth $0.7-1.0 \mathrm{~mm}$ long; cone body $4-6 \mathrm{~mm}$ long; cone bracts 2.0-2.5 $\mathrm{mm}$ high and broad; cones on long branchlets

C. terminale

$1^{*}$ Branchlet articles 2.5-5 mm long, 0.4-0.5 $\mathrm{mm}$ diameter; phyllichnia with an acute ridge; teeth $0.3-0.7 \mathrm{~mm}$ long; cone body $3-4 \mathrm{~mm}$ long; cone bracts 1-2 mm high and broad; cones on long or short branchlets

C. palawanense

\section{Ceuthostoma terminale $L$. Johnson, sp. nov.}

Arbor ad $30 \mathrm{~m}$ alta, cortice squamoso. Ramuli decidui $7-12 \mathrm{~cm}$ longi, articulis $4-7 \mathrm{~mm}$ longis, $0.7-0.9 \mathrm{~mm}$ diametro, laminis foliorum (dentibus) $0.7-1.0 \mathrm{~mm}$ longis, phyllichniis dorso rotundatis. Infructescentiae plerumque ramulos elongatos terminantes, corpore 4-6 mm longo, bracteis $2.0-2.5 \mathrm{~mm}$ altis latisque, bracteolis in seriebus fertilibus $1-2(-3)$, usque ad $5-7 \mathrm{~mm}$ protrudentibus.

Holotype: Borneo: Sabah: Penibukan, 4000-5000 ft [1220-1525 m], Mt Kinabalu, $J$. \& M.S. Clemens 30757, 7.i.1933 (K, O, infructescences). IsOTYPES: A, BO, L, NSW.

Tree to $30 \mathrm{~m}$ high, bark flaky or scaly. Deciduous branchlets $7-12 \mathrm{~cm}$ long, articles 4-7 mm long, 0.7-0.9 mm diameter, occasionally white-pubescent in the furrows, leaf laminae (teeth) narrow-deltoid, $0.7-1.0 \mathrm{~mm}$ long, phyllichnia dorsally rounded. Infructescenes ('cones') mostly terminal on elongated branchlets, somewhat white-pubescent, with $1-2(-3)$ fertile whorls; cone body 4-6 $\mathrm{mm}$ long; bracts $2.0-2.5 \mathrm{~mm}$ high and broad, not markedly striate; bracteoles protruding up to $5-7 \mathrm{~mm}$, with eccentric rib prominent dorsally; samara c. $6 \mathrm{~mm}$ long, wing hyaline. Fig. $1 \mathrm{a}, \mathrm{b}$.

Distribution: Known from a few isolated localities on the following islands: Borneo (on the slopes of Mt Kinabalu from 1000 to $2000 \mathrm{~m}$ ), Halmahera (Nucifera, Weda district) and New Guinea (Irian Jaya near Djayapura).

SPECIMEnS EXAmINED: Borneo: Sabah: Ulu, Mahandui, Mt Kinabalu, Carr SFN 26398, 6.iii.1933 (NSW, SING); Bembangan R., Mt Kinabalu, Chew \& Corner RSNB 4490, 4963, 23.ii.1964 (K); Pinosuk Plateau, Sungei Bembangan, Mt Kinabalu, Chew, Corner \& Stainton $1297(\mathrm{~K}, \mathrm{~L})$; spur ridge S. of Kinataki R., Mt Kinabalu, Clemens s.n. (BO); spur ridge S. of Kina Taki R., Penibukan, Mt Kinabalu, Clemens \& Clemens NSW 63028, 5.ii.1933 (NSW); Penibukan, Clemens \& Clemens 31312, 16.i.1933 (A, B, BO, L); Penataran R., Mt Kinabalu, Clemens \& Clemens 32576, 16.vi.1933 (A, BO, L); Penataran basin, Mt Kinabalu, Clemens \& Clemens 40154, $31 . v i i i .1933$ (A, BO, NSW); Lamag District: Mt Tavai, Karamuak, Kinabatongan, Meijer 51741, 19.vi.1965 (K); no precise locality, Clemens 3132 (A, B, BO, K), 50314 (A, K).

MALuKu: Halmahera, Nucifera, De Haan 1757, 26.ix.1950 (K); Halmahera, - (L).

NEW GuINEA: Irian Jaya: Hollandia [Djayapura], Brass 8820, vi-vii.1938 (A, BRI, NSW 63026), Versteegh 4704, 20.iii.1957 (CANB, L, LAE), van Royen \& Sleumer 6308, 26.vii.1961 (CANB, K, L); Cape Tanah Merah, van Royen \& Sleumer 6497, 7.viii.1961 (BRI, K, LAE).

$C$. terminale is found in places where the rainforest canopy is interrupted, on ridges and slopes. On Mt Kinabalu it has been recorded from the banks of the Penataran River, on ridges [granite] and old landslides, sometimes forming pure stands of small extent. On Halmahera it is said to occur on hills, on clayey yellow earth derived from weathered serpentine, and to be a very common tree '. . . used for construction and firewood'. Near Djayapura (formerly Hollandia) it is recorded from sea level to $200 \mathrm{~m}$ altitude in eroded places on lateritic soil near forest margins, or sometimes in the forest. The species is recorded as a tree 
6-30 m, with 'shaly [scaly?]' bark, with rounded crowns on old trees. In some of the New Guinea specimens the bark on the branches is thick, rough and corky, but this feature is not evident in the specimens from Borneo. The branchlets are said to be grey-green, which may be due in part to short hairs sometimes evident in the furrows. There appear to be slight differences between the populations in dimensions of cone-parts, but these may not be significant.

The specific epithet refers to the fact that the female inflorescences are mostly borne on elongated branchlets, thus appearing 'terminal' rather than 'lateral'.
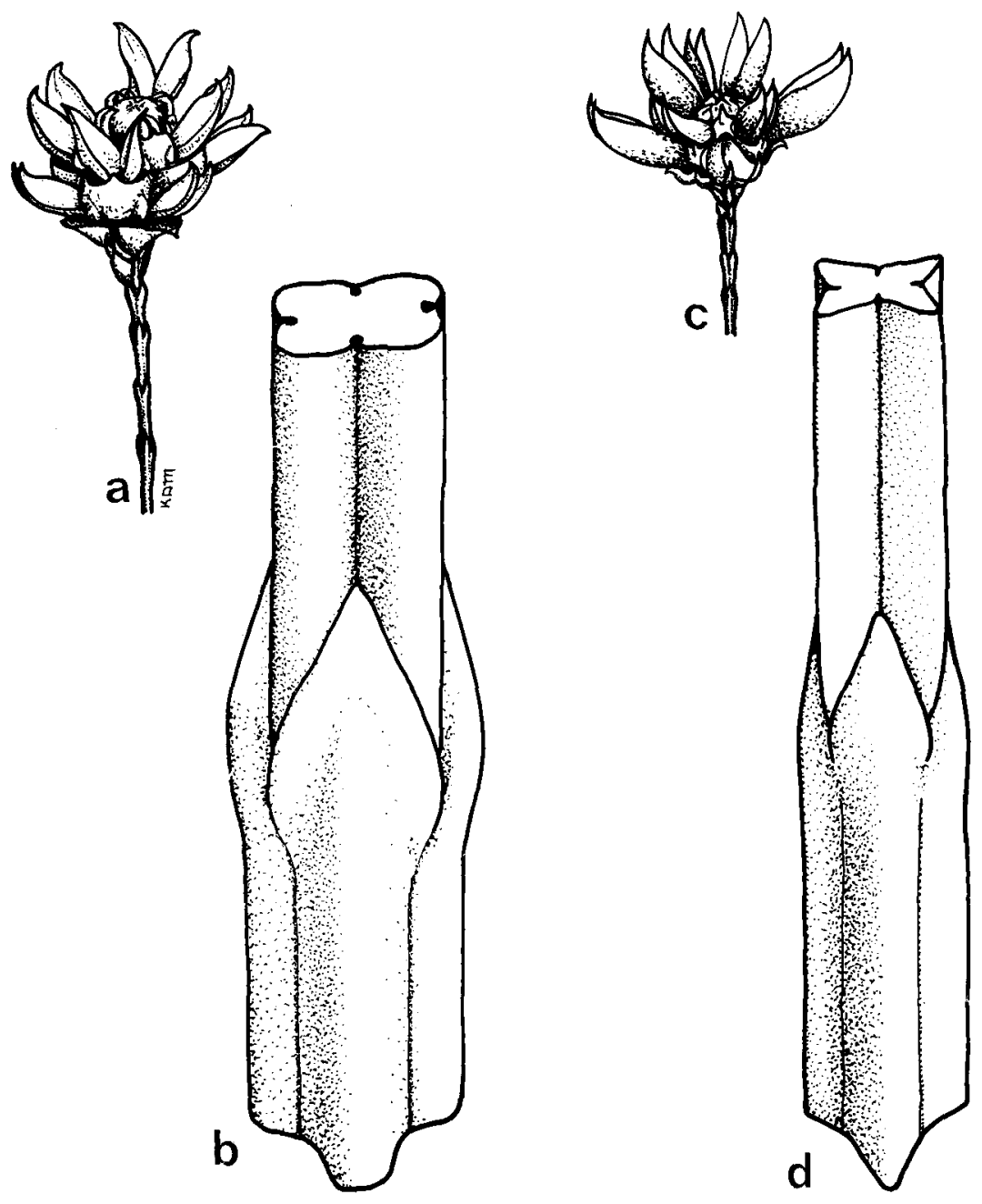

Fig. 1. Ceuthostoma terminale: a, infructescence $(\mathrm{X} 2.6)$; $\mathbf{b}$, portion of branchlet (X26). C. palawanense: c, infructescence (X2.6); d, portion of branchlet (X26). (a from NSW 63026; b from Clemens \& Clemens 40154; c from Foxworthy 710; d from Merrill 785). 


\section{Ceuthostoma palawanense L. Johnson, sp. nov.}

Arbor ad $10 \mathrm{~m}$ (vel altior?). Ramuli decidui circiter $6-8 \mathrm{~cm}$ longi, articulis 2.5-5 mm longis, $0.4-0.5 \mathrm{~mm}$ diametro, laminis foliorum $0.3-0.7 \mathrm{~mm}$ longis, phyllichniis dorso acutis. Infructescentiae ramulos breves vel modice elongatos terminantes, corpore 3-4 mm longo, bracteis $1-2 \mathrm{~mm}$ altis latisque, bracteolis in seriebus $1-2$, usque ad $5 \mathrm{~mm}$ protrudentibus.

Holotype: Philippines: Palawan ('Island of Paragua'): E-wi-ig River, E.D. Merrill 785, 18.ii.1903 (A, + , infructescences). IsOTYPES: K, NSW, NY, SING, US.

Tree to $10 \mathrm{~m}$ (or taller?). Deciduous branchlets c. $6-8 \mathrm{~cm}$ long, articles $2.5-5 \mathrm{~mm}$ long, $0.4-0.5 \mathrm{~mm}$ diameter, occasionally white-pubescent in the furrows, leaf laminae (teeth) narrow-deltoid, 0.3-0.7 mm long, phyllichnia dorsally acute. Infructescences ('cones') terminal on short or moderately elongated branchlets, somewhat fulvous-pubescent; cone body $3-4 \mathrm{~mm}$ long; bracts 1-2 mm high and broad, not markedly striate; bracteoles in 1-2 whorls, protruding up to $5 \mathrm{~mm}$, with eccentric rib dorsally; samara c. $6 \mathrm{~mm}$ long, wing chartaceous. Fig. $1 \mathrm{c}, \mathrm{d}$.

DiSTRIBUTION: Known only from four collections from the island of Palawan in the southwestern Philippines. Apart from the type locality, where it was said to occur along streams, it has been collected at $160 \mathrm{~m}$ altitude on the Malasgao River, at Aborlan, 'on the forest edge'. Although little known, C. palawanense clearly differs in its much more slender parts and acutely ridged phyllichnia from the more widely ranging $C$. terminale.

Specimens EXamined: Philippines: Palawan: Malasgao R., Aborlan, Edaño 14100, 10.iv.1951 (A, BR, L); no precise locality, Curran 3820, iii.1906 (K), Foxworthy BS 710, iii-iv.1906 (BO, L, NSW, NY, US).

\section{Acknowledgements}

My thanks are due to Mrs Karen Wilson for continuing assistance in many ways. $\mathrm{Mr}$ David Mackay drew the figure.

\section{References}

Johnson, L.A.S. (1980) Notes on Casuarinaceae [I]. Telopea 2: 83-84.

Johnson, L.A.S. (1982) Notes on Casuarinaceae II. J. Adelaide Bot. Gard. 6: 73-87.

Loew, E. (1865) 'De Casuarinearum caulis foliisque evolutione et structura' (Dissertatio inauguralis botanica, Berolini).

Manuscript received 17 June 1985.

Manuscript accepted 6 December 1985. 